\title{
ANALISIS PENGARUH CORPORATE SOCIAL RESPONSIBILITY (EKONOMI, LINGKUNGAN DAN SOSIAL) TERHADAP EARNING RESPONSE COEFFICIENT PADA PERUSAHAAN MANUFAKTUR DALAM ISSI 2012-2016
}

\author{
Budi Gautama Siregar \\ Institut Agama Islam Negeri Padangsidimpuan \\ Jalan T. Rizal Nurdin Km. 4,5 Sihitang, Padangsidimpuan \\ Email : budigautamasrg20@gmail.com
}

\begin{abstract}
Abstrak,
Penelitian ini bertujuan untuk mengetahui dan menganalisis pengaruh Corporate Social Responsibility (ekonomi, lingkungan dan social) terhadap earning response coefficient (ERC). Sampel penelitian in adalah perusahaan manufaktur yang sahamnya terindeks di ISSI dan IDX selama periode 2012-2016, sehingga total sampel 170. Teknik pengambilan sampel yang digunakan adalah saturated method sample dimana seluruh populasi digunakan dalam penelitian ini. Model analisis yang digunakan adalah SEM (Structural Equation Modeling) dimana teknik statistic tersebut mampu menganalisis pola hubungan antara konstruk laten dan indicator, konstruk laten dengan konstruk laten lainnya dan mengukur error secara langsung. SEM memungkinkan analisis langsung antara beberapa variable dependen dan independen. Hasil penelitian ini menunjukkan bahwa CSR berpengaruh negatif dan signifikan terhadap ERC saat Corporate Social Responsibility (CSR) diukur melalui social yang berpengaruh positif dan signifikan terhadap ERC.
\end{abstract}

Kata Kunci: Corporate Social Responsibility, Earning Response Coefficient, Manufaktur

\begin{abstract}
,
This study aims to examine and analyze the influence of Corporate Social Responsibility (measured by economic, environmental and social) on Earnings Response Coefficient. The sample used is a manufacturing company whose shares are incorporated in the ISSI on the IDX during the period 2012-2016, the total sample used is 170 samples. The sampling technique used is the saturated sample method where the entire population is used as a research sample. The analysis model used in this study is SEM (Structural Equation Modeling) in which a statistical technique is able to analyze the pattern of relationships between latent constructs and indicators, latent constructs with one another, and direct measurement errors. SEM allows direct analysis between several dependent and independent variables. This study found that Corporate Social Responsibility as measured by the economy and the environment had a negative and significant effect on Earning Response Coefficient while CSR as measured by social had a positive and significant effect on $E R C$.
\end{abstract}

Keywords: Corporate Social Responsibility, Earning Response Coefficient, Manufacture 
Analisis Pengaruh Corporate Social Responsibility (Ekonomi, Lingkungan dan Sosial) Terhadap Earning Response Coefficient pada Perusahaan Manufaktur Dalam ISSI 2012-2016

Budi Gautama Siregar

\section{PENDAHULUAN}

Laba merupakan salah satu indikator ukuran kinerja perusahaan. Informasi mengenai laba perusahaan merupakan prioritas pertimbangan utama oleh pihak pengguna laporan keuangan perusahaan dalam membuat keputusan investasi ataupun pertimbangan dalam memberikan kredit. Dengan adanya informasi yang relevan, pemakai dapat mengevaluasi peristiwa masa lalu, masa kini dan masa depan, menegaskan atau mengkoreksi hasil evaluasi mereka dimasa lalu. Informasi yang memiliki kualitas andal (reliabel) apabila bebas dari pengertian yang menyesatkan, kesalahan material dan dapat diandalkan pemakainya sebagai penyajian yang tulus dan jujur (faithfull representation) dari yang seharusnya disajikan atau yang secara wajar diharapkan dapat disajikan ( IAI, 1999).

Laba yang diinformasikan dalam laporan keuangan akan membuat pihak investor memberikan reaksi yang berbeda-beda. Reaksi pasar akan ditunjukkan dengan terjadinya perubahan return saham perusahaan dimana terdapat perbedaan yang cukup signifikan antara aktual return dengan expected return pada saat pengumuman (Suwardjono, 2005). Scot menyatakan bahwa kandungan informasi laba dapat dilihat dengan menggunakan ERC, yaitu menjelaskan dan mengindentifikasi perbedaan respon pasar terhadap pengumuman pasar. Besarnya hubungan antara laba dan return saham ini disebut dengan earnings response coefficient (Scott, 2009).

Kualitas laba di Indonesia lebih rendah dibandingkan dengan negara Asia lainnya dan negara maju. Indonesia dikategorikan sebagai salah satu negara yang penegakan hukumnya rendah dan perusahaan-perusahaan di Indonesia cenderung memiliki konsentrasi kepemilikan yang tinggi (Lang dan Lundholm, 1993). Kandungan informasi laba yang rendah pada perusahaan-perusahaan di Indonesia menimbulkan adanya kebutuhan informasi pesaing laporan keuangan yaitu informasi di luar laporan keuangan. Dalam penelitian digunakan informasi mengenai corporate social responsibility.

Hal ini juga didorong banyaknya kasus lingkungan, adanya peraturan yang mewajibkan perseroan terbatas melaksanakan kegiatan corporate social responsibility, diterbitkannya ISO 26000 yang menjadikan corporate social responsibility sebagai salah satu hal penting yang diperhatikan semua pihak dan sudah banyak diterapkan sebagai bagian dari kegiatan perusahaan. Sudah banyak penelitian-penelitian sebelumnya yang melakukan penelitian tentang corporate social responsibility tetapi hasilnya masih belum konsisten, diantaranya Kartadjumena meneliti tentang pengaruh voluntary disclosure of financial information dan corporate social responsibility terhadap earnings response coefficient. Hasilnya menunjukkan bahwa corporate social responsibility tidak berpengaruh signifikan terhadap earnings response coefficient, namun secara parsial voluntary disclosureof financial information berpengaruh 
positif terhadap earnings response coefficient, sebaliknya corporate social responsibility berpengaruh negatif terhadap earning response coefficient (Kartadjumena, 2010).

Pradipta dan Purwaningsari meneliti tentang pengaruh luas pengungkapan tanggung jawab sosial dan lingkungan perusahaan terhadap earnings response coefficient dengan ukuran dan leverage sebagai variabel control. Hasilnya menunjukkan bahwa luas pengungkapan tanggung jawab sosial dan lingkungan perusahaan berpengaruh negatif terhadap earnings response coefficient (Hayu dan Purwaningsih, 2011). Wulandary dan Wirajaya meneliti tentang pengaruh pengungkapan corporate social responsibility terhadap earnings response coefficient, hasilnya menunjukkan bahwa pengungkapan corporate social responsibility tidak berpengaruh secara signifikan terhadap earnings response coefficient. Selanjutnya Restuti et.al (2012) meneliti tentang pengaruh pengungkapan corporate social responsibility terhadap earnings response coefficient, hasilnya menunjukkan bahwa pengungkapan corporate social responsibility tidak berpengaruh terhadap earning respons coefficient (Wulandari dan Wirajaya, 2014).

Berdasarkan latar belakang diatas, maka penelitian berjudul analisis pengaruh Corporate Social Responsibility (Ekonomi, Lingkungan dan Sosial) terhadap Earning Response Coefficient pada Perusahaan Manufaktur dalam ISSI 2012-2016. Sehingga rumusan masalah penelitian ini adalah apakah Corporate Social Responsibility yamg diukur dengan ekonomi dapat mempengaruhi Earnings Response Coefficient, Apakah Corporate Social Responsibility yamg diukur dengan lingkungan dapat mempengaruhi Earnings Response Coefficient, Apakah Corporate Social Responsibility yamg diukur dengan sosial dapat mempengaruhi Earnings Response Coefficient. Berdasarkan permasalahan tersebut maka tujuan penelitian ini adalah untuk menguji dan menganalisis pengaruh Corporate Social Responsibility yang diukur dengan ekonomi terhadap Earnings Response Coefficient, untuk menguji dan menganalisis pengaruh Corporate Social Responsibility yang diukur dengan lingkungan terhadap Earnings Response Coefficient, untuk menguji dan menganalisis pengaruh Corporate Social Responsibility yang diukur dengan sosial terhadap Earnings Response Coefficient.

\section{TINJAUAN TEORITIK}

\section{Teori Legitimasi}

Legitimasi adalah suatu kondisi dimana sistem nilai merupakan sebuah entitas sama dengan sistem nilai dari sistem sosial masyarakat dimana suatu entitas menjadi bagian dari masyarakat (Lang dan Lundholm, 1993). Lahirnya teori legitimasi dilandasi adanya kontrak sosial antara masyarakat dan perusahaan dalam menggunakan sumber ekonomi. Perwujudan 
Analisis Pengaruh Corporate Social Responsibility (Ekonomi, Lingkungan dan Sosial) Terhadap Earning Response Coefficient pada Perusahaan Manufaktur Dalam ISSI 2012-2016

Budi Gautama Siregar

legitimasi dalam dunia bisnis dapat berupa pelaporan aktivitas sosial yang berupa tanggung jawab sosial perusahaan.

Legitimasi organisasi dapat terlihat sebagai sesuatu yang diberikan masyarakat kepada perusahaan dan merupakan sesuatu yang diinginkan perusahaan dari masyarakat. Maka legitimasi merupakan manfaat atau sumber potensial bagi perusahaan untuk bertahan hidup. Apabila terjadi perbedaan nilai yang dianut perusahaan dengan nilai yang berlaku dimasyarakat, maka legitimasi perusahaan tersebut berada pada posisi yang terancam. Dalam perspektif teori legitimasi, perusahaan dan komunitas sekitarnya memiliki relasi sosial yang erat karena keduanya terikat dalam social contract.

\section{Earning Response Coefficient}

Informasi yang terkandung dalam laba biasanya sangat direspon oleh para investor dalam proses pengambilan keputusannya. Atas respon tersebut maka akan dapat diketahui apakah pengumuman laba mengandung informasi yang relevan bagi pengambilan keputusan investor atau tidak. Value relevance dari laba dapat dilihat dari terjadinya abnormal return dan perubahan volume perdagangan saham di sekitar tanggal pengumuman laba (Nugrahanti, 2010). Kunci utama untuk mengukur pasar efisien adalah hubungan antara harga sekuritas dengan informasi. Fama menyajikan tiga macam bentuk utama dari efisiensi pasar, yaitu informasi masa lalu, informasi yang sedang dipublikasikan dan informasi private. Salah satu informasi yang digunakan investor dalam pengambilan keputusan adalah informasi mengenai pengumuman laba(Fama, 1970).

Pengertian Koefisien Respon Laba (Earnings Response Coefficient) menurut Cho dan Jung adalah sebagai berikut koefisien respon laba didefinisikan sebagai efek setiap dolar unexpected earnings terhadap return saham, dan biasanya diukur dengan slopa koefisien dalam regresi abnormal returns saham dan unexpected earning (Cho dan Jung, 1991).

Selanutnya Cho dan Jung mengklasifikasi pendekatan teoritis ERC menjadi dua kelompok yaitu (1) model penilaian yang didasarkan pada informasi ekonomi (information economics based valuation model) seperti dikembangkan oleh Holthausen dan Verrechia dan Lev yang menunjukkan bahwa kekuatan respon investor terhadap sinyal informasi laba (ERC) merupakan fungsi dari ketidakpastian di masa mendatang. Semakin besar noise dalam system pelaporan perusahaan (semakin rendah kualitas laba), semakin kecil ERC dan (2) model penilaian yang didasarkan pada time series laba (time series based valuation model) (Holthausen dan Verrechia, 1988).

Scott mendefinisikan earning respons coeficient merupakan slope yang mengukur hubungan laba perusahaan yang menerbitkan sekuritas terhadap return sahamnya (Scott, 2006). Hayn mengatakan bahwa earning response coefficient untuk perusahaan yang rugi pada umumnya lebih kecil dibandingkan dengan earning response coefficient untuk perusahaan yang 
memperoleh laba. Earning yang tinggi akan mencerminkan laba yang berkualitas (Hayn, 1995). Cheng dan Nasir menyatakan bahwa earning response coefficient merupakan estimasi perubahan harga saham perusahaan akibat dari informasi laba perusahaan yang diumumkan ke pasar (Cheng dan Nasir, 2010).

Berdasarkan penjelasan diatas maka dapat disimpulkan bahwa earnings response coefficient merupakan suatu reaksi yang datang dari pengumuman laba perusahaan. Reaksi ini ditunjukkan dengan adanya perubahan saham. Return saham menggambarkan perilaku investor karena adanya informasi yang bernilai yang diperolehnya. Perilaku investor tersebut dapat berupa melakukan investasi atau tidak.

\section{Corporate Social Responsibility}

Definisi CSR menurut World Bank dalam Public Policy for Corporate Social Responsibility tahun 2003 adalah "the commitment of business to contribute to sustainable economic development, working with employees, their families, the local community and society at large to improve quality of life, inways that are both good for business and good for development".

Berdasarkan definisi World Bank diatas, CSR diartikan sebagai komitmen bisnis untuk berkontribusi terhadap pembangunan ekonomi yang berkelanjutan, bekerja sama dengan pekerja, keluarga mereka, komunitas lokal dan masyarakat secara luas untuk meningkatkan kualitas hidup, dengan cara-cara yang baik untuk bisnis dan juga baik untuk pembangunan. Menurut World Business Council for Sustainable Development (WBCSD) dalam id.wikipedia.org, "CSR merupakan suatu komitmen berkelanjutan oleh dunia usaha untuk bertindak etis dan memberikan kontribusi kepada pengembangan ekonomi dari komunitas setempat atau pun masyarakat luas, bersamaan dengan peningkatan taraf hidup pekerjanya beserta seluruh keluarganya".

Maignan dan Ferrel mendefinisikan CSR sebagai "A business acts in socially responsible manner when its decision and actions account for and balance diverse stakeholder interest". Tindakan bisnis dikatakan bertanggung jawab secara sosial ketika keputusan dan tindakan yang diambil memperhitungkan dan menyeimbangkan seluruh kepentingan stakeholders yang beragam.

Berdasarkan berbagai definisi diatas, CSR dilakukan perusahaan untuk memenuhi tanggungjawabnya kepada pihak pemegang saham, pemerintah, lingkungan sosial, komunitas dan masyarakat. Pemenuhan tanggung jawab sosial ini dapat dilakukan dengan berbagai bentuk sesuai dengan kepentingan para shareholders. Dengan dilaksanakannya CSR, perusahaan tidak hanya berupaya untuk memenuhi kebutuhan shareholders, namun juga memenuhi kebutuhan keberlangsungan usahanya ke depan. Pelaksanaan kegiatan CSR menurut Kotler (2005) dapat 
Analisis Pengaruh Corporate Social Responsibility (Ekonomi, Lingkungan dan Sosial) Terhadap Earning Response Coefficient pada Perusahaan Manufaktur Dalam ISSI 2012-2016

Budi Gautama Siregar

dibagi kedalam enam kategori, yaitu (1) cause promotions, (2) causerelated marketing, (3) corporate social marketing, (4) corporate philanthropy, (5)community volunteering, dan (6) socially responsible Business Practice.

\section{Corporate Social Responsibility dengan Earning Response Coefficient}

Corporate social responsibility bertujuan mengurangi asimetri informasi ketika informasi laba hanya memberikan sedikit informasi tentang nilai perusahaan. Laporan tahunan adalah salah satu media yang digunakan oleh perusahaan untuk berkomunikasi langsung dengan para investor. CSR tidak berpengaruh Terhadap Laba Perusahaan Manufaktur yang tergabung dalam LQ 45, hasil penelitian ini sama dengan penelitian Sayekti dimana CSR berpengaruh negatif terhadap ERC. Kegiatan CSR merupakan salah satu informasi yang dipublikasikan perusahaan disamping laporan keuangan perusahaan (Sayekti dan Wondabio, 2007).

Bird et al. dalam penelitiannya menemukan bahwa pasar merespon semua aktivitas CSR yang diungkapkan oleh perusahaan. menemukan bahwa investor individual tertarik terhadap informasi sosial yang diungkapkan dalam laporan keuangan perusahaan. Informasi tersebut mencakup keamanan dan kualitas produk, etika dan hubungan dengan karyawan dan masyarakat. Mary Beth Holbrook mengatakan bahwa perusahaan dianggap hanya bertanggung jawab secara sosial karena terkait laba akuntansi untuk meningkatkan reaksi pasar (Ball dan Brown, 1968).

Berdasarkan uraian diatas maka dapat disimpulkan bahwa CSR merupakan salah satu informasi yang diungkapkan perusahaan dalam laporan tahunannya, sehingga dapat dirumuskan bahwa kegiatan CSR berpengaruh terhadap Earnings Response Coefficient (ERC).

\section{METODE PENELITIAN}

\section{Jenis Penelitian}

Jenis penelitian ini adalah penelitian kuantitatif, berdasarkan karakteristik masalah yang diteliti, penelitian ini dapat diklasifikasikan ke dalam penelitian kausal komparatif.

\section{Lokasi Penelitian}

Penelitian ini dilakukan pada perusahaan manufaktur go publik yang bersaham syariah dan terdaftar di Indeks Saham Syariah Indonesia dengan periode pengamatan 2012-2016 yang diperoleh melalui situs resmi Bursa Efek Indonesia.

\section{Jenis dan Sumber Data}

Jenis data yang digunakan dalam penelitian ini merupakan data sekunder dan telah dipublikasikan oleh Bursa Efek Indonesia melalui ICMD dari tahun 2012-2016.

Adapun data yang diperlukan adalah laporan keuangan yang sesuai dengan variabel penelitian, yaitu kegiatan Corporate Social Responsibility dan Earning Response Coefficient.

\section{Instrumen Penelitian}


Instrumen merupakan alat pengumpulan data yang dipilih dan digunakan untuk mempermudah peneliti dan mengumpulkan data tersebut sehingga menjadi sistematis dan mudah. Instrumen dalam penelitian ini informasi yang dilaporkan perusahaan dalam memenuhi seluruh variabel-variabel dalam penelitian ini.

\section{Populasi dan Sampel}

(Cooper dan Emory, 1999) menyebutkan bahwa populasi adalah kumpulan individu atau obyek penelitian yang memiliki kualitas serta ciri-ciri yang telah dtetapkan. Berdasarkan pada kualitas dan ciri-ciri yang minimal memiliki satu persamaan karakteristik. Populasi yang digunakan dalam penelitian ini adalah seluruh perusahaan manufaktur yang go publik bersaham syariah dalam ISSI yang terdaftar di Bursa Efek Indonesia mulai dari tahun 2012 sd 2016 yang memiliki laporan keuangan lengkap dan dipublikasikan dalam Indonesia Capital Market Directory (ICMD).

\section{Definisi Operasional dan Pengukuran Variabel}

Berdasarkan kajian teori dan hasil-hasil penelitian sebelumnya, maka secara ringkas pengukuran variabel dalam penelitian ini adalah :

Tabel 1

Pengukuran Variabel Penelitian

\begin{tabular}{|c|c|c|c|}
\hline $\begin{array}{c}\text { Jenis } \\
\text { Variabel }\end{array}$ & Definisi & Parameter & Scala \\
\hline \multicolumn{4}{|c|}{ Variabel Independen (X) } \\
\hline $\begin{array}{l}\text { Corporate } \\
\text { Social } \\
\text { Responsibil } \\
\text { ity (X) }\end{array}$ & \multicolumn{2}{|c|}{$\begin{array}{l}\text { CSR dalam penelitian ini adalah dalam hal lingkungan, } \\
\text { sosial dan governance.. }\end{array}$} & \\
\hline $\begin{array}{l}\text { Ekonomi } \\
\quad\left(\mathrm{X}_{1}\right)\end{array}$ & $\begin{array}{lr}\text { Kegiatan } & \text { CSR } \\
\text { perusahaan } & \text { yang } \\
\text { berkenaan } & \text { dengan } \\
\text { lingkungan } & \\
\end{array}$ & $C S R_{E}=\frac{\Sigma X_{i j}}{n_{j}}$ & Rasio \\
\hline $\begin{array}{l}\text { Lingkungan } \\
\quad\left(\mathrm{X}_{2}\right)\end{array}$ & $\begin{array}{l}\text { Kegiatan CSR yang } \\
\text { meliputi } \quad \text { unsur- } \\
\text { unsur sosial }\end{array}$ & $C S R_{L}=\frac{\Sigma X_{i j}}{n_{j}}$ & Rasio \\
\hline Sosial $\left(\mathrm{X}_{3}\right)$ & $\begin{array}{lr}\text { Kegiatan } & \text { CSR } \\
\text { perusahaan } & \text { yang } \\
\text { berkenaan } & \text { dengan } \\
\text { tata kelola. } & \\
\end{array}$ & $C S R_{S}=\frac{\Sigma X_{i j}}{n_{j}}$ & Rasio \\
\hline \multicolumn{4}{|c|}{ Variabel dependen } \\
\hline $\begin{array}{l}\text { Earnings } \\
\text { Response } \\
\text { Coefficient }\end{array}$ & $\begin{array}{l}\text { Suatu reaksi yang } \\
\text { datang dari } \\
\text { pengumuman } \\
\text { laba perusahaan. }\end{array}$ & $\begin{array}{l}\text { Langkah-Langkah: } \\
\text { a. Abnormal return } \\
\mathrm{AR}_{\mathrm{it}}=\mathrm{R}_{\mathrm{it}}-\mathrm{RM}_{\mathrm{it}}\end{array}$ & Rasio \\
\hline
\end{tabular}




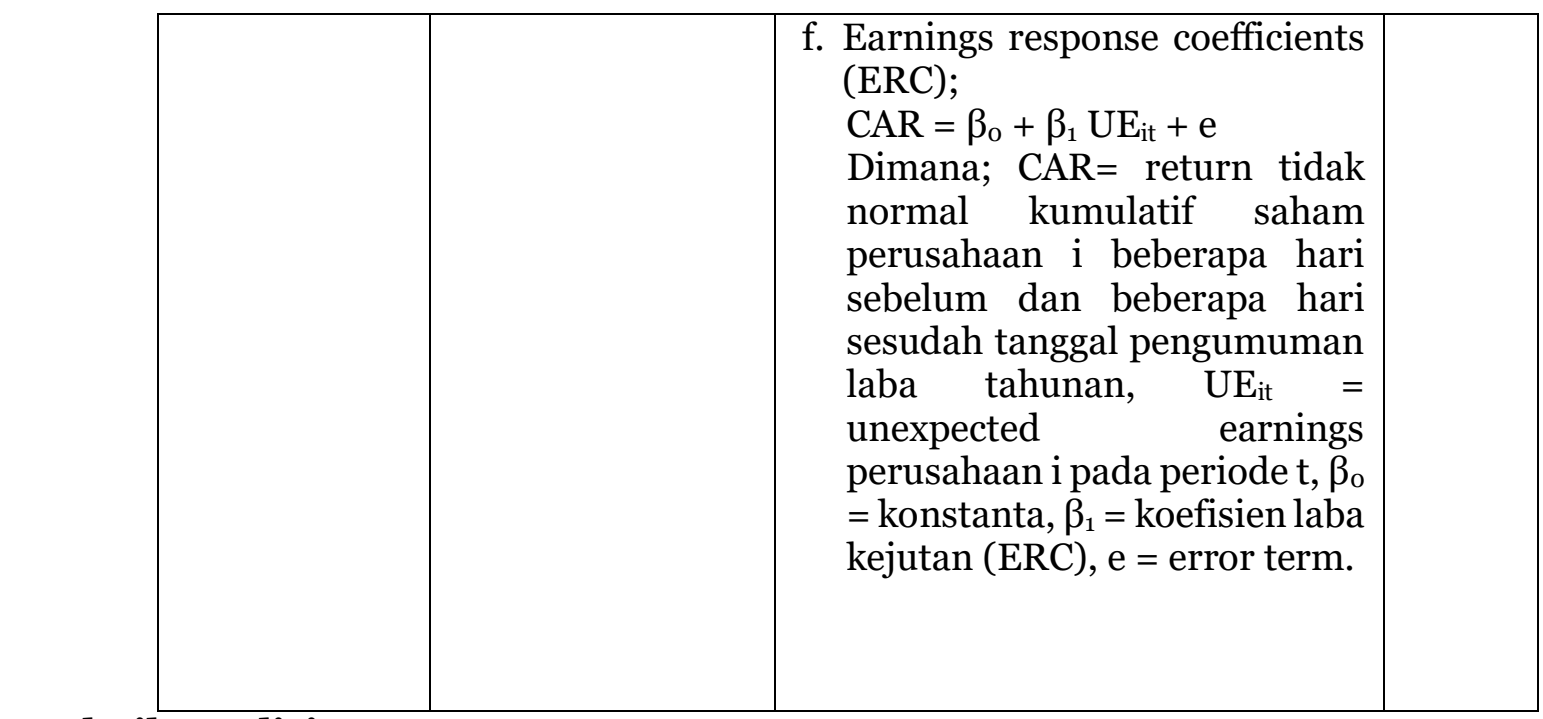

Teknik Analisis Data

Teknik analisis dalam penelitian ini dilakukan dengan Structural Equation Model (SEM). Model yang digunakan adalah path analysis yang tujuannya untuk menganalisis pola hubungan antar variable agar diketahui pengaruh langsung maupun tidak langsung seperangkat variable bebas terhadap variable terikat (Riduwan dan Engkos, 2007). Selanjutnya Teknik pengolahan data dengan menggunaan metode SEM berbasis Partial Least Square (PLS) dengan SmartPLS.

\section{HASIL DAN PEMBAHASAN}

\section{Model Pengukuran variable Corporate Social Responsibility}

Variabel Corporate Social Responsibility terdiri dari 3 indikator dan bobot masingmasing indikator dalam merefleksikan variabel adalah sebagai berikut :

Tabel 2

Bobot Faktor Indikator Variabel CSR

\begin{tabular}{|c|r|r|r|}
\hline Indikator & $\begin{array}{c}\text { Loading } \\
\text { Factor }\end{array}$ & \multicolumn{1}{|c|}{$\mathrm{R}^{2}$} & T Statistics \\
\hline Ekonomi & 0.756 & 0,738 & 2,255 \\
\hline Lingkungan & 0.839 & 0,468 & 2,303 \\
\hline Sosial & 0.734 & 0,365 & 1,978 \\
\hline Composite reliability(CR)=0,821 \\
\hline Average Variance Extracted(AVE) $=0,605$
\end{tabular}

Sumber : Hasil Output SmartPLS

Berdasarkan tabel 2 tersebut diatas dapat diketahui bahwa semua nilai bobot faktor untuk masing-masing indikator lebih besar dari 0,5. Dilakukan pengujian dengan melihat nilai $t_{\text {hitung }}$

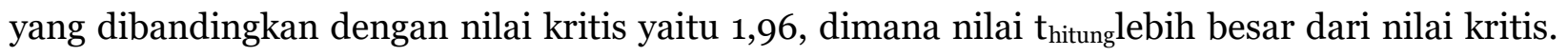


Analisis Pengaruh Corporate Social Responsibility (Ekonomi, Lingkungan dan Sosial) Terhadap Earning Response Coefficient pada Perusahaan Manufaktur Dalam ISSI 2012-2016

Budi Gautama Siregar

Data ini menunjukkan bahwa ketiga indikator signifikan dalam merefleksikan variabel Corporate Social Responsibility.

Nilai Composite Reliability (CR) untuk variabel Corporate Social Responsibility sebesar o,821, hal ini menunjukkan bahwa tingkat kesesuaian indikator dalam merefleksikan variabel Corporate Social Responsibility lebih besar dari yang direkomendasikan yaitu 0,70. Sedangkan nilai Average Variance Extracted (AVE) sebesar 0,605, nilai ini menunjukkan bahwa secara ratarata 60,5 \% informasi yang terdapat pada ketiga indikator dapat tercermin melalui variabel Corporate Social Responsibility.

\section{Model Pengukuran Variabel Earning Response Coefficient}

Variabel Earning Response Coefficient terdiri dari 1 indikator dan bobot faktor indikator dalam merefleksikan variabel adalah sebagai berikut :

Tabel 3

Bobot Faktor Indikator Variabel Earning Response Coefficient

\begin{tabular}{|l|c|c|c|}
\hline \multicolumn{1}{|c|}{ Indikator } & $\begin{array}{c}\text { Loading } \\
\text { Factor }\end{array}$ & $\begin{array}{c}\text { Composite } \\
\text { Reliability }\end{array}$ & $\begin{array}{c}\text { Average } \\
\text { Variance } \\
\text { Extracted }\end{array}$ \\
\hline $\begin{array}{l}\text { Cumulative Abnormal Return } \\
\text { (CAR) }\end{array}$ & 1,000 & 1,000 & 1,000 \\
\hline
\end{tabular}

Sumber : Hasil Output SmartPLS

Dari tabel 3 diatas dapat diketahui bahwa nilai bobot faktor, Composite Reliability (CR) dan Average Variance Extracted (AVE) sebesar 1,000 karena variabel Earning Response Coefficient digambarkan oleh satu indicator.

\section{Pengujian Hipotesis}

Setelah dilakukan pengujian terhadap model pengukuran, selanjutnya dilakukan pengujian hipotesis melalui model struktural. Hipotesis yang akan diuji pada penelitian ini adalah pengaruh Corporate Social Responsibility (yang diukur dengan ekonomi, lingkungan dan sosial) berpengaruh terhadap Earnings Response Coefficient pada perusahaan Manufaktur yang terdaftar dalam ISSI pada BEI periode 2012-2016. Hipotesis diuji menggunakan uji t dengan nilai kritis sebesar 1,96. Berikut ini hasil pegolahan data dengan SmartPLS model PLS Algorithma dan model t-value (Bootstrapping): 


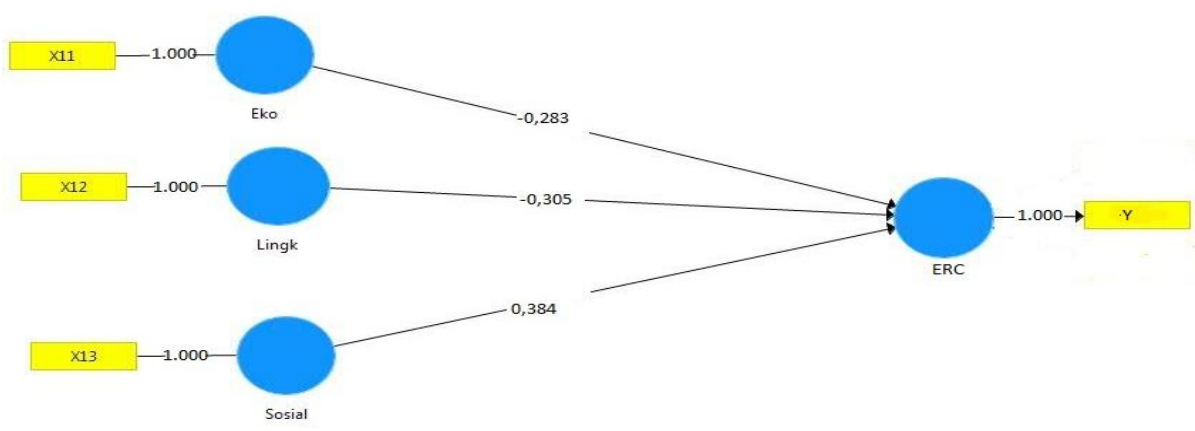

Gambar 1 Diagram Jalur Hasil Run SmartPls Algorithma Sumber : Hasil Output SmartPls

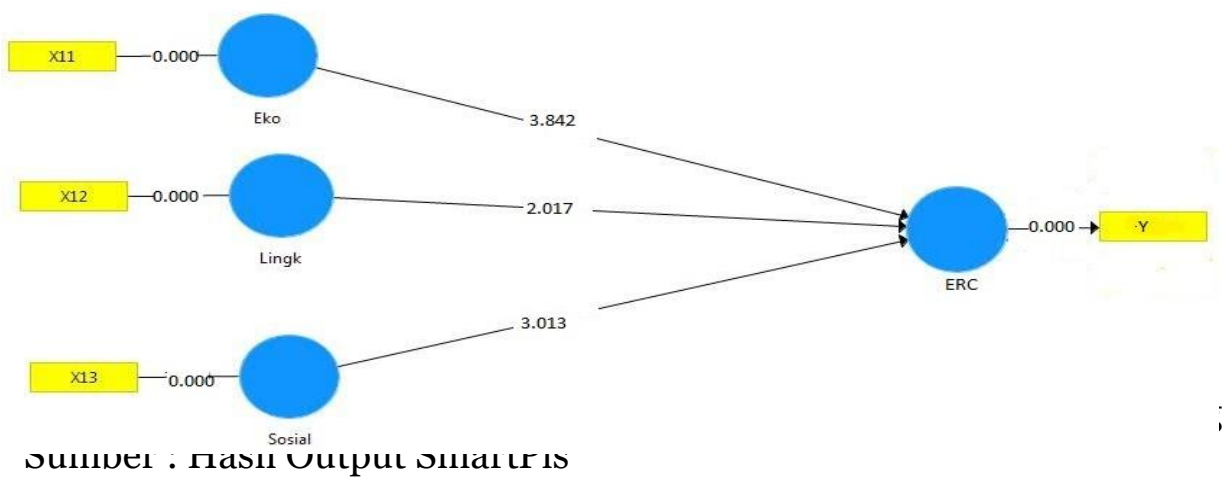

Pengaruh Corporate Social Responsibility yang diukur dengan ekonomi terhadap earning response coefficient

Berdasarkan hasil pengolahan data dengan menggunakan program SmartPls diperoleh hasil:

Tabel 4

Hasil Uji Pengaruh corporate social responsibility yang diukur dengan ekonomi terhadap Earning Response Coefficient

\begin{tabular}{|l|c|c|c|c|c|}
\hline \multicolumn{1}{|c|}{ Jalur } & Koefesien & $\mathbf{t}_{\text {hitung }}$ & p-value & $\mathbf{H}_{\mathbf{o}}$ & $\mathbf{H}_{\mathbf{1}}$ \\
\hline $\begin{array}{l}\text { Eko (X1) -> ERC } \\
\text { (Y) }\end{array}$ & -0.283 & 3.842 & 0.040 & & Diterima \\
\hline
\end{tabular}

Sumber : Hasil Output SmartPLS 3.0

Dari tabel 4 diatas dapat dilihat bahwa nilai t-hitung jalur Corporate Social Responsibility yang diukur dengan ekonomi terhadap Earning Response Coefficient sebesar 3.842 dengan nilai Probability sebesar 0,040. Karena nilai $t_{\text {hitung }}$ (3.842) lebih besar dibandingkan dengan $t_{\text {kritis }}(1,96)$ pada tingkat kekeliruan 5\%, sehingga dapat diputuskan bahwa Corporate Social Responsibility 
Analisis Pengaruh Corporate Social Responsibility (Ekonomi, Lingkungan dan Sosial) Terhadap Earning Response Coefficient pada Perusahaan Manufaktur Dalam ISSI 2012-2016 Budi Gautama Siregar

yang diukur dengan ekonomi berpengaruh terhadap Earning Response Coefficient pada perusahaan manufaktur yang terdaftar dalam ISSI di Bursa Efek Indonesia dengan koefisien sebesar -0,283 dan bertanda negatif, maka dapat disimpulkan bahwa Corporate Social Responsibiliy yang diukur dengan ekonomi memiliki pengaruh negatif terhadap Earning Response Coefficient. Artinya, semakin tinggi Corporate Social Responsibility yang diukur dengan ekonomi maka akan menurunkan Earning Response Coefficient.

\section{Pengaruh Corporate Social Responsibility yang diukur dengan lingkungan terhadap earning response coefficient}

Berdasarkan hasil pengolahan data dengan menggunakan program SmartPls diperoleh hasil:

Tabel 5

Hasil Uji Pengaruh corporate social responsibility yang diukur dengan lingkungan terhadap Earning Response Coefficient

\begin{tabular}{|l|c|c|c|c|c|}
\hline \multicolumn{1}{|c|}{ Jalur } & Koefesien & $\mathbf{t}_{\text {hitung }}$ & $\boldsymbol{p}$-value & $\mathbf{H}_{\mathbf{0}}$ & $\mathbf{H}_{\mathbf{1}}$ \\
\hline $\begin{array}{l}\text { Lingk (X2) -> ERC } \\
\text { (Y) }\end{array}$ & -0.305 & 2.017 & 0.044 & & Diterima \\
\hline
\end{tabular}

Sumber : Hasil Output SmartPLS 3.0

Dari tabel 5 diatas dapat dilihat bahwa nilai t-hitung jalur Corporate Social Responsibility yang diukur dengan lingkungan terhadap Earning Response Coefficient sebesar 2.017 dengan nilai Probability sebesar 0,044. Karena nilai $t_{\text {hitung }}$ (2.017) lebih besar dibandingkan dengan $t_{\text {kritis }}$ $(1,96)$ pada tingkat kekeliruan 5\%, sehingga dapat diputuskan bahwa Corporate Social Responsibility yang diukur dengan lingkungan berpengaruh terhadap Earning Response Coefficient pada perusahaan manufaktur yang terdaftar dalam ISSI di Bursa Efek Indonesia dengan koefisien sebesar -0,305 dan bertanda negatif, maka dapat disimpulkan bahwa Corporate Social Responsibiliy yang diukur dengan lingkungan memiliki pengaruh negatif terhadap Earning Response Coefficient. Artinya, semakin tinggi Corporate Social Responsibility yang diukur dengan lingkungan maka akan menurunkan Earning Response Coefficient.

Pengaruh Corporate Social Responsibility yang diukur dengan sosial terhadap earning response coefficient.

Berdasarkan hasil pengolahan data dengan menggunakan program SmartPls diperoleh hasil:

Tabel 6

Hasil Uji Pengaruh corporate social responsibility yang diukur dengan sosial terhadap Earning Response Coefficient 
At-Tijaroh: Jurnal Ilmu Manajemen dan Bisnis Islam

Volume 4 Nomor 1 Ed. Januari - Juni 2018 : hal. 96-111

p-ISSN: 2356-492X e-ISSN : 2549-9270

\begin{tabular}{|l|c|c|c|c|c|}
\hline \multicolumn{1}{|c|}{ Jalur } & Koefesien & $\mathbf{t}_{\text {hitung }}$ & p-value & Ho $_{\mathbf{0}}$ & H $_{\mathbf{1}}$ \\
\hline $\begin{array}{l}\text { Sosial (X3) -> ERC } \\
\text { (Y) }\end{array}$ & 0.384 & 3.013 & 0.040 & & Diterima \\
\hline
\end{tabular}

Sumber : Hasil Output SmartPLS 3.0

Dari tabel 6 diatas dapat dilihat bahwa nilai t-hitung jalur Corporate Social Responsibility yang diukur dengan sosial terhadap Earning Response Coefficient sebesar 3.013 dengan nilai Probability sebesar 0,040. Karena nilai $t_{\text {hitung }}$ (3.013) lebih besar dibandingkan dengan $\mathrm{t}_{\mathrm{kritis}}(1,96)$ pada tingkat kekeliruan 5\%, sehingga dapat diputuskan bahwa Corporate Social Responsibility yang diukur dengan sosial berpengaruh terhadap Earning Response Coefficient pada perusahaan manufaktur yang terdaftar dalam ISSI di Bursa Efek Indonesia dengan koefisien sebesar 0.384 dan bertanda positif, maka dapat disimpulkan bahwa Corporate Social Responsibiliy yang diukur dengan sosial memiliki pengaruh positif terhadap Earning Response Coefficient. Artinya, semakin tinggi Corporate Social Responsibility yang diukur dengan sosial maka akan meningkatkan Earning Response Coefficient.

Berdasarkan hipotesis penelitian yaitu bahwa Corporate Social Responsibility yang diukur dengan ekonomi, lingkungan dan sosial berpengaruh terhadap Earnings Response Coefficient. Berdasarkan hasil pengujian statistik diperoleh hasil bahwa CSR yang diukur dengan

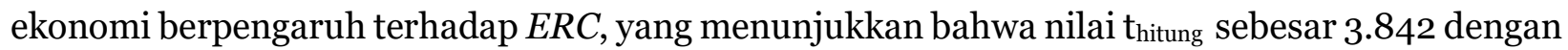
nilai probability sebesar 0.040. Nilai $t_{\text {hitung }}(3.842)$ lebih besar dibandingkan dengan nilai $t_{\text {kritis }}$ $(1,96)$ pada tingkat kekeliruan $5 \%$ dengan nilai koefisien -0.283, sehingga dapat disimpulkan bahwa CSR yang diukur dengan ekonomi berpengaruh negative dan signifikan terhadap $E R C$.

Pengaruh CSR yang diukur dengan lingkungan terhadap $E R C$ diperoleh nilai nilai thitung sebesar 2.017 dengan nilai probability sebesar 0.044. Nilai thitung (2.017) lebih besar dibandingkan dengan nilai $t_{\text {kritis }}(1,96)$ pada tingkat kekeliruan $5 \%$ dengan nilai koefisien -0.305, sehingga dapat disimpulkan bahwa CSR yang diukur dengan lingkungan berpengaruh negative dan signifikan terhadap ERC. Demikian dengan pengaruh CSR yang diukur dengan sosial terhadap ERC diperoleh nilai $t_{\text {hitung }}$ sebesar 3.013 dengan nilai probability sebesar 0.040. Nilai thitung (3.013) lebih besar dari nilai $t_{\text {kritis }}(1,96)$ pada tingkat kekeliruan $5 \%$ dengan nilai koefisien 0.384, sehingga dapat disimpulkan bahwa CSR yang diukur dengan sosial berpengaruh positif dan signifikan terhadap ERC. Hasil ini sejalan dengan penelitian yang dilakukan oleh Ghadiri et.al (2013), Bae dan Sami, 2005; Sayekti \& Wondabio, (2007); Hidayanti \& Murni, (2009); Pradipta \& Purwaningsih, (2012), Dwijayanti (2013) dan Siregar, at.al (2018) yang menyatakan bahwa Corporate Social Responsibility memberikan pengaruh negatif dan signifikan terhadap Earning 
Analisis Pengaruh Corporate Social Responsibility (Ekonomi, Lingkungan dan Sosial) Terhadap Earning Response Coefficient pada Perusahaan Manufaktur Dalam ISSI 2012-2016

Budi Gautama Siregar

Response Coefficient. Hal ini mengindikasikan bahwa investor dapat mempertimbangkan informasi tanggungjawab sosial dan lingkungan sebagai bahan pertimbangan dalam keputusan berinvestasi selain informasi laba dan bertentangan dengan penelitian yang dilakukan oleh Indah, (2001), Rasmiati, (2002); Zuhroh et al, (2003); Kartajumena, (2010); Wulandary dan Wirajaya (2014); Rasti et.al (2012); Riski Oktovaia Lestari, (2013); Fitri Hidayat, (2014), yang tidak menemukan hubungan yang signifikan antara pengungkapan sosial dengan volume perdagangan saham seputar publikasi laporan tahunan. Hal ini dapat diartikan bahwa investor belum memperhatikan informasi-informasi sosial yang diungkapkan dalam laporan tahunan perusahaan sebagai informasi yang dapat mempengaruhi investor dalam melakukan keputusan investasi. Investor masih menganggap informasi laba lebih bermanfaat dalam menilai perusahaan dan dianggap lebih mampu memberikan informasi untuk mendapatkan return saham yang diharapkan oleh investor dibandingkan dengan informasi sosial yang diungkapkan oleh perusahaan.

Dalam membuat keputusan investasi para investor tidak hanya mengandalkan informasi laba saja tetapi sudah mempertimbangkan kegiatan CSR perusahaan. Ini mengindikasikan bahwa investor mengapresiasi informasi CSR yang diungkapkan dalam laporan tahunan perusahaan (Sayekti dan Wondabio, 2007). Pertimbangan para investor tersebut akan mempengaruhi respon pasar terhadap laba perusahaan (ERC), karena investor tidak hanya menggunakan informasi laba saja dalam membuat keputusan investasi tetapi juga menggunakan informasi yang terkandung dalam laporan CSR. Ini berarti informasi yang terkandung dalam CSR akan mengurangi atau berpengaruh negatif terhadap tingkat pemakaian informasi laba oleh investor.

\section{KESIMPULAN}

Berdasarkan hasil analisis data serta pembahasan yang dilakukan pada bagian sebelumnya, maka kesimpulan dari penelitian ini bahwa Corporate Social Responsibility yang diukur dengan ekonomi dan lingkungan berpengaruh negative dan signifikan terhadap Earnings Response Coefficient sedangkan CSR yang diukur dengan sosial berpengaruh positif dan signifikan terhadap ERC. Temuan ini sejalan dengan Ghadiri et.al yang menyatakan bahwa Corporate Social Responsibility memberikan pengaruh negatif dan signifikan terhadap Earning Response Coefficient.

Dengan adanya kegiatan CSR yang dilaporkan dalam laporan tahunan perusahaan, perlahan diharapkan adanya nilai tambah dan legitimasi dari masyarakat terhadap operasional perusahaan maupun produk yang dihasilkannya. Dalam membuat keputusan investasi para investor tidak hanya mengandalkan informasi laba saja tetapi sudah mempertimbangkan 
kegiatan CSR perusahaan. Ini mengindikasikan bahwa investor mengapresiasi informasi CSR yang diungkapkan dalam laporan tahunan perusahaan.

\section{DAFTAR PUSTAKA}

Ball, R. Dan P. Brown, 1968, An Empirical Evaluation of Accounting Income Numbers, Journal of Accounting Research, Autumn : 159-178

Cho, J.Y and K. Jung. (1991). Earnings Response Coefficient: A Sythesis of Theory and Empirical Evidence. Journal of Accounting Literature. 10: 85-116.

Cheng, F.F., \& Nasir, A. (2010). Earning response coefficients and the financial risks of China commercial banks. International Review of Business Research Papers, 6(3), 178 - 188

Cooper, Donal R. dan Emory, William, 1999. Metode Penelitian Bisnis, alih bahasa Widyono Soecipto dan Uka Wikarya, Jilid 11, Jakarta: Erlangga

Fama, Eugene F. (May 1970), "Efficient market: A review of theory and empirical work", Journal of Finance , 25 (2): 383-417.

Ghozali, Imam. 2008. Aplikasi Analisis Multivariate dengan Program SPSS. Semarang: Badan Penerbit Universitas Diponegoro

Holthausen dan Verrechia (1988). The Effect of Sequential Information Release on The Variance of Price Changes In An Intertemporal Multi Assets Market. Journal of Accounting Research 26 (spring), pp.82-106

Hayn, C. 1995. The Information Content of Losses. Journal of Accounting and Economics 20 (September): 125-153

Ikatan Akuntan Indonesia, 1999. Standar Akuntansi Keuangan. PSAK No. 17, Cetakan Keempat, Buku Satu, Penerbit Salemba Empat, Jakarta

Kartadjumena, Eriana. 2010. Pengaruh Voluntary Disclosure of Financial Information dan CSR Disclosure Terhadap Earning Response Coefficient. Jurnal akuntansi (Online).

Lang, Mark and Lundholm, Russel. 1993. Cross-Sectional Determinants of Analist Ratings of Corporate Disclosure. Journal of Accounting (online), Vol 31, No. 2

Nugrahanti, Yeterina Widi. 2010. Pengaruh Corporate Social Responsibility (CSR)Disclosure Terhadap Kinerja Perusahaan. Proceedings Call for Paper Seminar Atmajaya. 25-26 Mei 2010

Pradipta, Dyah Hayu dan Anna Purwaningsih. 2011. Pengaruh Luas Pengungkapan Tanggung Jawab Sosial Dan Lingkungan Perusahaan Terhadap Earning Response Coefficient (ERC), Dengan Ukuran Perusahaan Dan Leverage Sebagai Variabel Kontrol. Artikel. Universitas Atmajaya. Yogyakarta. 
Analisis Pengaruh Corporate Social Responsibility (Ekonomi, Lingkungan dan Sosial) Terhadap
Earning Response Coefficient pada Perusahaan Manufaktur Dalam ISSI 2012-2016 Earning Response Coefficient pada Perusahaan Manufaktur Dalam ISSI 2012-2016
Budi Gautama Siregar

Riduwan dan Engkos Achmad Kuncoro. 2007. Cara Menggunakan dan Memaknai Analisis Jalur (Path Analysis). Bandung : Alfabeta.

Suwardjono. 2005. Teori Akuntansi: Perekayasaan Pelaporan Keuangan, Edisi Ketiga. Yogyakarta: BPFE

Scott, William R. 2009, Financial Accounting Theory, 5 th Ed. Canada: Prentice-Hall

, William R. (2006). Financial Accounting Theory. 4th Edition. United States of America: Pearson Prentice Hall.

Siregar, Gautama, B,. 2018, Influence Analysis of Corporate Social Responsibility, Default Risk and Conservatisme on Earning Response Coefficient through Earning Management in Stockholding Manufacturing Company Joined in Indonesia Sharia Stock Index, Journal of Applied Economic Science, Volume XIII, Summer, 3(57): 729 - 741.

Siregar, Gautama, B., Ade, F.L., Azhar, M., F. 2018, Analysis Of Corporate Social Responsibility, Default Risk And Conservatism Effect To Earning Management With Good Corporate Governance As Moderating Variable In Manufacturing Company Whose Shares Incorporated In Indonesia Sharia Stock Index, Junior Scientific Researcher, Vol IV, No. 1, pp. 14-33.

Sayekti, Y. dan Wondabio, L.S. 2007. Pengaruh CSR Disclosure Terhadap Earning Response Coefficient (Studi Empiris Pada Perusahaan yang Terdaftar di Bursa Efek Jakarta). Simposium Nasional Akuntansi X. Makassar

Wulandari, K. T., \& Wirajaya, I. G. (2014). Pengaruh Pengungkapan Corporate Social Responsibility terhadap Earning Response Coefficient. E-Jurnal Akuntansi Universitas Udayana, 6(3), 355-369 